\title{
PENGARUH KOMPENSASI DAN KEPUASAN KERJA KARYAWAN PADA CV. PRABU TIRTA GUNUNG JEMBRANA
}

\author{
D.D. Putri ${ }^{1}$, N.M.A. Widiastini ${ }^{2}$ \\ 1,2, Jurusan Manajemen, Universitas Pendidikan Ganesha, Singaraja \\ e-mail:dwidillianaputri@gmail.com, ary.widiastini@undiksha.ac.id
}

\begin{abstract}
Abstrak
Penelitian ini bertujuan untuk mengetahui pengaruh kompensasi dan kepuasan kerja terhadap kinerja karyawan pada CV. Prabu Tirta Gunung Jembrana. Pada penelitian ini menggunakan desain kuantitatif kausal. Dengan menggunakan populasi yaitu pemimpin dan seluruh karyawan yang ada pada CV. Prabu Tirta Gunung Jembrana yang berjumlah 33 orang. Adapun data yang akan digunakan pada penelitian ini adalah variabel kompensasi, kepuasan kerja dan variabel kinerja karyawab. Kemudian data tersebut akan dikumpulkan dengan menggunakan teknik kuesioner dan akan dianalisis menggunakan analisis jalur. Adapun hasil dari penelitiian telah menunjukan adanya pengaruh positif dari (1) kompensasi terhadap kinerja karyawan, (2) kepuasan kerja terhadap kinerja karyawan, (3) kompensasi terhadap kepuasan kerja karyawan, dan yang ke (4) kompensasi terhadap kinerja melalui kepuasan kerja karyawan pada CV. Prabu Tirta Gunung Jembrana.
\end{abstract}

Kata Kunci : kompensasi, kepuasan kerja, kinerja karyawan

\begin{abstract}
This study aims to see the effect of compensation and job satisfaction on employee performance at CV. Prabu Tirta Gunung Jembrana. The causal quantitative research design was used in this study. The population in this study were the leaders and all employees of CV. Prabu Tirta Gunung Jembrana who can be said to be 33 people. The data needed in this study is data on compensation, job satisfaction and employee performance. The data was collected using a questionnaire technique, then analyzed the line of analysis. The results of this study indicate that there is a positive influence between (1) compensation for employee performance, (2) job satisfaction on employee performance, (3) compensation on employee job satisfaction, (4) compensation on performance through employee job satisfaction at CV. Prabu Tirta Gunung Jembrana.
\end{abstract}

Keywords: compensation, employee performance, job satisfaction

\section{Pendahuluan}

Persaingan yang terjadi didunia perbisnisan saat ini semakin hari semakin ketat. Hal ini dapat mengakibatkan setiap perusahaan berusaha untuk dapat bertahan dalam situasi yang sulit.manajemen sumber daya manusia yang dimilikinya termasuk untuk meningkatkan kinerja karyawan. Iklim bisnis Indonesia tidak terlepas dari adanya isu-isu global yang disebabkan oleh perubahan struktur pasar Indonesia dalam perdagangan. Penanggulangan yang bisa dilakukan dalam menghadapi persaingan tersebut yaitu melalui upaya dalam memajukan daya saing, baik pada product sampai dengan tingkat kualitas production diperusahaan. Perusahaan tidak hanya memiliki modal besar saja dalam mencapai tujuan namun perusahaan juga perlu memperhatikan faktor pendukung lainnya yakni alam, tenaga kerja (manusia) dan keahlian. Dimana ketiga faktor pendukung tidak dapat berdiri sendiri akan tetapi perlu adanya saling mendukung satu sama lainnya dalam menggapai tujuan dari perusahaan baik secara efektif maupun secara efisien.

Persaingan usaha saat ini dapat membuat perusahaan kerap berusaha demi dapat memberikan suatu keyakinan dan jaminan jika produk yang akan diberikan dapat mendukung adanya upaya dalam menciptakan rasa puas dari konsumen. Pada masingmasing perusahaan selalu berusaha untuk merancang strategi untuk membuat konsumen selalu bertahan dan tidak memilih mengonsumsi produk yang lain. Oleh karena itu, sudah pasti terdapat persaingan yang semakin hari semakin ketat diantara perusahaan yang memproduksi air mineral. Perusahaan Air Minum Dalam Kemasan (AMDK) memanfaatkan 
adanya perkembangan teknologi untuk dapat memberikan peningkatan dari kualitas produknya serta dapat menciptakan inovasi-inovasi yang baru dengan tujuan dapat bersaing dengan perusahaan di bidang yang sama.

Menurut Surat Keputusan Menteri Perindustrian dan Perdagangan RI No. 705/MPP/Kep/11/2003, dijelaskan bahwa air minum dalam kemasan (AMDK) dapat diartikan sebagai sebuah produk air yang bersifat baku yang mengalami proses tidak menggunakan bahan pangan yang lainnya serta tidak menggunakan bahan pangan tambahan. Produk ini dikemas dengan tujuan menjaga keamanan pada saat mengkonsumsinya dan air ini sudah memiliki pemenuhan syarat-syarat atas kualitas dari air bersih yang mana nantinya dapat diolah dan diproses untuk dijadikan AMDK. Hal tersebut memberikan dukungan pada kegiatan dalam pelaksanaan pemilihan umum yang mana memberikan peningkatan pada konsumsi atas AMDK pada pasar di dalam negeri.

CV (Comanditarire Venootschap) yang sering disebut dengan persekutuan komanditer dapat diartikan sebagai suatu badan dalam bidang usaha yang dibangun dengan modal yang terbatas yang mana dibentuk atas dasar kerjasama diantara dua atau lebih pihak. CV. Prabu Tirta Gunung Jembrana merupakan perusahaan-perusahaan yang mana berjalan pada produksi air minum, dalam perkembangannya banyak perusahaan yang muncul dalam bidang yang sama seperti industri air minum dalam kemasan sangat banyak. Perusahaaan CV. Prabu Tirta Gunung Jembrana yang memproduksi air minum dalam kemasan $220 \mathrm{ml}$ (cup). Perusahaan ini berdiri sejak tahun 2013 hingga sekarang yang beralamat di Jl. Panji Sakti 17x Sawe Rangsase-Jembrana, Bali. Perusahaan CV. Prabu Tirta Gunung dengan merek dagang Prabu Gunung memiliki karyawan berjumlah sebanyak 33 orang.

Kinerja dapat diartikan sebagai sebuah hasil dari sebuah pekerjaan yang dapat dilihat melalui kualitas ataupun kuantitas yang telah dihasilkan dalam upaya melaksanakan tugastugasnya yang disesuaikan dengan apa yang telah menjadi tanggungjawabnya (Mangkunegara, 2005). Baiknya kinerja ialah kinerja yang mampu memenuhi target dari ketentuan suatu perusahaan tersebut. Apabila kinerjanya tidak sinkron dengan yang di inginkan oleh pihak perusahaan maka kepuasan yang dirasakan oleh karyawan rendah dan mengakibatkan kinerja karyawan rendah. Mangkunegara (2009) menyebutkan bahwa indikator yang mendasari adanya kinerja adalah kualitas, kuantitas, pelaksanaan tugas dan tanggung jawab.

Kompensasi adalah unsur yang sangat dibutuhkan yang dapat mempengaruhi kinerja karyawan. Kompensasi dapat diartikan sebagai seluruh pendapatan yang diterima oleh karyawan dalam bentuk uang atau barang atas imbalan yang diberikan karena telah memberikan jasanya pada pihak perusahaan. Selain itu kompensasi merupakan salah satu cara dalam meningkatkan prestasi kerja atau kinerja dari karyawan Mathis dan Jackson (2006) yang mana sebuah kompensasi sangat memberikan efek pada kinerja dari masingmasing karyawan karena dengan adanya diberikan kompensasi ini atas kinerja yang telah karyawan berikan dapat membantu karyawan dalam meningkatkan kinerjanya tersebut. Adapun indikator yang mempengaruhi kompensasi menurut Mathis dan Jackson (2016) meliputi kompensasi yang bersifat langsung dan tidak.

Selain unsur kompensasi, ada unsur lain yang mempengaruh kinerja karyawan yaitu variabel kepuasan kerja. Kepuasan kerja dapat diartikan sebagai perasaan puas dari seseorang atas hasil yang didapat dari hal-hal dan tugas yang dikerjakannya serta rasa puas akan imbalan yang didapatkan dari pekerjaan tersebut. Kepuasan dari suatu kerja diartikan sebagai sikap-sikap yang mana seseorang menyukai pekerjaan yang telah dibuat (Hasibuan, 2012). Sikap ini dapat dilihat dari beberapa hal seperti sikap disiplin dari orang tersebut, prestasi dalam bekerja, kepuasan kerja yang mana dinikmati baik dari dalam, luar pekerjaan maupun keduanya. Kepuasan kerja juga dapat berarti sebuah alat ukur perusahaan dalam pemenuhan harapan dari karyawan yang berkaitan dalam berbagai aspek pada pekerjaan dan jabatan. Adapun indikator dari kepuasan kerja menurut Sudaryo \& Dkk (2018) meliputi pekerjaannya, atasan atau jabatan yang lebih tinggi, rekan-rekan dalam bekerja dan kesempatan promosi. 
Permasalahan yang terjadi pada kinerja karyawan CV Prabu Tirta Gunung adalah kuantitas kerja dan tanggung jawab karyawan yang belum maksimal yang disebabkan oleh karyawan yang sering meminta izin di jam kerja kepada atasan. Hal ini mempengaruhi hasil produksi yang sudah ditargetkan oleh perusahaan tersebut. Diduga faktor yang mempengaruhi rendahnya kinerja karyawan sebagaimana yang ditemukan pada perusahaan CV. Prabu Tirta Gunung Jembrana yaitu kompensasi yang rendah dan kepuasan kerja

Berdasarkan observasi awal pada CV. Prabu Tirta Gunung Jembrana yaitu terjadinya permasalahan dimana pemberian kompensasi tidak sesuai dengan upah minimum kabupaten (UMK), dimana UMK pada Kabupaten Jembrana pada tahun 2019 sebesar Rp 2.356.559 kemudian pada tahun 2020 naik sebesar Rp 2.557.102. Sehingga hasil kerja karyawan tidak sesuai dengan target yang ditentukan oleh perusahaan. Dalam penerapannya pemberian gaji dibagi menjadi dua yaitu pemberian gaji untuk karyawan bulanan dan pemberian gaji untuk karyawan mingguan. Pemberian kompensasi yang kurang terhadap karyawan dapat mempengaruhi kinerja dari karyawan dan menyebabkan ketidakpuasan karyawan.

Berdasarkan hasil observasi pada CV. Prabu Tirta Gunung Jembrana ditemukan karyawan merasa kurang puas atas hasil kerja yang diberikan atasan yang membuat karyawan tidak menyelesaikan pekerjaan dengan baik karena gaji yang tekag didapatkan dapatkan tidak selaras dengan pekerjaan yang mereka capai. Pada hal, semakin sesuai gaji ataupun upah yang didapatkan pihak karyawan, karyawan juga akan merasa puasa dan mampu meningkatkan kinerja. Hal ini didukung oleh penelitian menurut Hendro( 2018) mengatakan kompensasi dan kepuasan kerja memiliki pengaruh yang postif terhadap kinerja karyawan.

Dari penjelasan latar belakang masalah terdapat fakta yang terjadi pada kinerja dari karyawan pada CV. Prabu Tirta Gunung Jembrana masih kurang optimal, hal tersebut dikarenakan masih rendahnya pemberian kompensasi dan kepuasan kerja karyawan dapat mempengaruhi kinerja dari karyawan CV. Prabu Tirta Gunung Jembrana. Oleh karena itu, perlu adanya kegiatan penelitian dengan judul "Pengaruh Kompensasi Dan Kepuasan Kerja Terhadap Kinerja Karyawan Pada CV. Prabu Tirta Gunung Jembrana".

Melalui penjelasan dari latar belakang masalah tersebut, adapun rumusan masalah yang dapat diajukan dalam melakukan penelitian ini adalah sebagai berikut: (1) Bagaimana efek yang diberikan kompensasi pada kinerja karyawan pada CV. Prabu Tirta Gunung Jembrana, (2) Bagaimana efek yang diberikan kepuasan kerja pada kinerja karyawan pada CV. Prabu Tirta Gunung Jembrana, (3) Bagaimana efek yang diberikan kompensasi pada kepuasan kerja karyawan pada CV. Prabu Tirta Gunung Jembrana, (4) Bagaimana efek yang diberikan kompensasi pada kinerja melalui kepuasan kerja karyawan pada CV. Prabu Tirta Gunung Jembrana.

Adapun pembatasan masalah dari penelitian ini yaitu peneliti membatasi variabel penelitian yang hanya terdiri dari tiga variabel yang terdiri dari dua variabel bebas dan satu variabel terikat. Kompensasi dan Kepuasan Kerja sebagai variabel bebas, kemudian kinerja karyawan sebagai variabel terikat. Berdasarkan pembatasan masalah, maka tujuan dari penelitian ini adalah untuk mengetahui besar pengaruh: (1) Kompensasi pada kinerja karyawan pada CV. Prabu Tirta Gunung Jembrana, (2) Kepuasan kerja pada kinerja karyawan pada CV. Prabu Tirta Gunung Jembrana, (3) Kompensasi pada Kepuasan kerja karyawan pada CV. Prabu Tirta Gunung Jembrana, (4) Kompensasi pada kinerja melalui kepuasan kerja karyawan pada CV. Prabu Tirta Gunung Jembrana.

Adapun pendapat dari Mangkunegara (2005) yang menjelaskan bahwa kinerja merupakan sebuah pencapaian kerja secara kualitas dan kuantitas, dimana kualitas yang dimaksud adalah seseorang yang memiliki kemampaun dalam mendapatkan tujuannya serta dapat melebihi tujuan yang telah ditentukan oleh sebuah perusahaan tersebut. Sementara secara kuantitasnya adalah keahlian seseorang dalam menyelesaikan pekerjaan dengan hasil yang maksimal dan dalam kurung waktu yang telah ditentukan, sehingga seorang karyawan dapat mengimplementasikan seluruh tanggungjawabnya pada pekerjaan yang dikerjakan. Sedangkan menurut Rachmawati (2009) yang menyatakan bahwa suatu 
pencapain yang dicapai oleh satu orang atau lebih disebuah perusahaan, selaras dengan tanggung jawabnya dan melakukan pelanggaran apapun.

Menurut Mangkunegara (2009) ukuran indikator kinerja dapat dikelompokkan dalam empat kategori yaitu: (1) Kualitas kerja yaitu ukuran seberapa besar pemahan kayawan serta terhadap pekerjaannya serta kualitas yang dimiliki karyawan tersebut, (2) Kuantitas kerja yaitu mengukur seberapa cepatnya karyawan dalam melakukan pekerjaan, (3) Pelaksanaan tugas yaitu menilai apakah karyawan bisa melaksanakan pekerjaannya secara setail tanpa melakukan satu kesalahan saat bekerja, (4) Tanggung jawab yaitu apakah karyawan mampu memengang teguh amanah serta tanggung jawab yang dilimpahkan dari perusahaan kepada pihak karyawan tersebut.

Variabel yang memiliki peran yang paling penting yang biasa meningkatkan kinerja karyawan yaitu kompensasi. dalam hal ini adapun pendapat dari Hasibuan (2012) yaitu semua jenis penghasilan yang berupa gaji serta penghasilan beruapa barang secara langsung ataupun tidak langsung. Selain itu adapun cara dalam meningkatkan prestasi kerja atau kinerja dari karyawan. Adapun pendapat dari (Mathis dan Jackson, 2006) kompensasi merupakan suatu strategi dalam menaikan tingkat kemapuan kerja serta kinerja dari karyawan (Wirawan, 2009).

Dengan kata lain bahwa sebuah kompensasi merupakan faktor sangat berpengaruh terhadap kinerja karyawan karena dengan pemberian kompensasi yang sesuai dengan kinerja yang telah karyawan berikan baik itu berupa pemberian gaji pokok, gaji variabel, dan benefit dapat membantu dalam meningkatkan kinerja dari karyawan tersebut. Keahlian perusahaan dalam melakukan pemberian imbalan yang sesuai dengan hasil kerja dari karyawan ini dapat memberikan manfaat untuk seluruh kehidupan dari perusahaan.

Menurut Mathis (2016) kompensasi dapat diukur melalui beberapa indikator yang meliputi: (1) Kompensasi Langsung yaitu penghargaan yang akan diberikan oleh suatu perusahaan kepada karyawan berupa gaji pokok dan tunjangan atas pekerjaan yang telah dihasilkannya, (2) Kompensasi Tidak Langsung yaitu program penghargaan yang akan diberikan kepada karyawan yang memiliki kinerja yang bagus berupa pemberian benefit dari perusahaan, bisa berupa asuransi kecelakaan, asuransi jiwa serta berupa cuti khusus.

Kepuasan kerja yaitu sesuatu yang dirasakan oleh para karyawan didalam suatu lingkungan pekerjaannya atas peranan yang diberikan dalam sebuah perusahaan serta kebutuhan dari para karyawan terpenuhi dengan baik. Menurut Hasibuan (2012) yang menyatakan bahwa suatu perilaku yang bagus dan mencintai pekerjaannya itu merupakan suatu cerminan dari kedisplinan, moral serta hasil kerja dan kepuasan kerja itu merupakan bentuk apresisasi karayawan dalam melakukan pekerjaan. Selain itu ada pendapat lain dari (Kuswadi, 2004) yang menyatakan bahawa kepuasan kerja dapat dilihat seberapa mampunya pihak perusahaan bisa memenuhi keinginan dari karyawan dan jabatan yang ditanggung oleh setiap karyawan. Dengan demikian kepuasan kerja sangat memberikan efek pada kinerja karyawan, kepuasan kerja diartikan sebagai suatu rasa puas yang dirasakan oleh seseorang atas hasil kerja yang dikerjakannya serta rasa puas akan imbalan yang didapatkan dari pekerjaan tersebut. Menurut pendapat dari Sudaryo \& Dkk (2018) yang menyatakan bahwa kepuasan kerja dapat dilihat dari beberapa indikator yaitu: (1) Pekerjaan itu sendiri yaitu kemapuan seseorang dalam mengatasi serta menyelesaikan sebuah projek yang diperikan oleh perusahaan tersebut (2) Atasan yaitu yang memberikan perintah serta yang bertanggung jawab dalam mengatur karyawan serta pekerjaan dan yang menelolah sebuah perusahaan, (3) Rekan kerja yaitu teman kerja yang selalu berinteraksi serta yang menjadikan sebuah persaingan dalam mengerjakan sebuah projek, seseorang dapat mengenali apakah rekan sekerjanya memiliki sifat yang baik atau sebaliknya, (4) Kesempatan promosi yaitu sebuah kesempatan untuk bisa mengembangkan karir serta dapat manaiki jabatan sesuai dengan apa yang diberikan kepada perusahaan.

Adapun hubungan kompensasi terhadap kinerja karyawan. Kompensasi merupakan faktor yang paling penting serta berpengaruh terhadap peningkatan kinerja karyawan. adapun pendapat dari (Mathis dan Jackson, 2006) yang menyatakan bahwa terdapat cara manajemen dalam menaikan kemampuan kerja atau kinerja dari yaitu dengan cara 
pemberian kompensasi. Hal ini juga sependapat dengan (Hasibuan, 2009) menyatakan bahwa pemberian sebuah kompensasi yang bagus bisa memberikan peningkatan dari kinerja karyawan tersebut. H.1: kompensasi berpengaruh terhadap kinerja karyawan CV. Prabu Tirta Gunung Jembrana.

Adapun hubungan kepuasan kerja terhadap kinerja karyawan. yaitu suatu kepuasan yang dirasakan oleh seseorang akan hasil kerja yang dikerjakannya serta rasa puas akan imbalan yang didapatkan dari pekerjaan tersebut. Menurut Affandi (2016) semakin tinggi rasa puas yang dirasakan oleh karyawan akan dapat membuat karyawan lebih meningkatkan kinerja, secara tidak langsung karyawan akan lebih maksimal dalam mengerjakan pekerjaan serta dapat menyelesaikan pekerjaan dengan lebih kreatif dan baik. Adapun menurut Robbins (2012) seorang yang memilki tingkat kepuasan pada pekerjaan yang besar akan membuat seseorang tersebut selalu memiliki persaan yang baik dalam melakukan pekerjaannya sebaliknya seseorang dengan keadaan tidak baik dalam bekerja akan berdapak negative dalam melakukan pekerjaannya. H.2: kepuasan kerja berpengaruh terhadap kinerja karyawan CV. Prabu Tirta Gunung Jembrana.

Adapun hubungan kompensasi terhadap kepuasan kerja. Salah satu cara dalam meningkatkan kinerja dari karyawan ialah dengan memberikan kompensasi. hal tersebut sama dengan pendapat dari (Sunyoti, 2012) yang menyatakan bahwa struktur pemberian kompensasi yang bagus yaitu sebuah struktur yang dapat mampu menjamin kepuasan dari karyawan, semakin bagus struktur pemberian kompensasi maka akan semakin tinggi tingkat kepuasan yang akan dirasakan. Hal ini didukung oleh penelitian yang dilakukan oleh Putra (2016) yang menyatakan bahwa ada pengaruh positif dari variabel kompensasi terhadap variabel kepuasan kerja. H.3: kompensasi berpengaruh terhadap kepuasan kerja karyawan CV. Prabu Tirta Gunung Jembrana. Kemudian Ada hubungan antara kompensasi terhadap kinerja melalui kepuasan kerja Kompensasi dan kepuasan kerja merupakan faktor yang dapat mempengaruhi terhadap peningkatan kinerja karyawan. Menurut penelitian dari Hendro (2018) kompensasi dan kepuasan kerja berpengaruh signifikan secara parsial dan simultan terhadap kinerja karyawan, hal ini didukung oleh kajian empiris dari Putra (2016) ada pengaruh positif kompensasi dan kepuasan kerja terhadap kinerja karyawan. Hal ini dapat disimpulkan bahwa kompensasi dan kepuasan kerja, kedua variabel tersebut dapat berpengaruh pada peningkatan kinerja karyawan. H.4: kompensasi berpengaruh terhadap kinerja melalui kepuasan kerja karyawan CV. Prabu Tirta Gunung Jembrana.

\section{Metode}

Dalam melakukan penelitian ini yaitu dengan menggunakan desain kausal yang diketahui berguna untuk bisa menganalisis hubungan antara satu variabel dengan hubungan variabel lainnya. Adapun analisis data yang akan dugunakan dalam penelitian ini yaitu dengan memakai analisis jalur (Path Analysis), dan desain penelitian ini menggunakan desain dari kuantitatif kausal tersebut yang terdiri dari beberapa tahapan yang mencakup merancang rumusan masalah terlebih dahulu, kemudian membuat kajian teori yang mendukung, kemudian hipotesis dirumuskan, mengumpulkan data, data kemudian diolah dan akhirnya ditarik simpulan. Kemudian penelitian ini dilakukan untuk mengetahui pengaruh kompensasi $\left(\mathrm{X}_{1}\right)$ dan kepuasan kerja $\left(\mathrm{X}_{2}\right)$ terhadap kinerja karyawan $(\mathrm{Y})$ pada $\mathrm{CV}$. Prabu Tirta Gunung Jembrana. Adapun variabel bebasnya adalah kompensasi dan kepuasan kerja, sedangkan variabel terikatnya adalah kinerja karyawan.

Subjek penelitian yang akan diteliti dalam penelitian ini adalah pemimpin dan karyawan yang bekerja pada CV. Prabu Tirta Gunung Jembrana, sedangkan objeknya pada penelitian ini adalah kompensasi $\left(\mathrm{X}_{1}\right)$, kepuasan kerja $\left(\mathrm{X}_{2}\right)$ dan kinerja karyawan $(\mathrm{Y})$ pada CV. Prabu Tirta Gunung Jembrana. Sugiyono (2017) menjelaskan bahwa populasi dapat diartikan sebagai suatu area yang secara umum dapat dijadikan bahan untuk melakukan penelitian yang mana terdiri dari objek atau subjek yang mana di dalamnya memiliki karakteristik yang dapat dipelajari lebih dalam. Populasi penelitian ini ialah pemimpin dan seluruh karyawan yang bekerja pada CV. Prabu Tirta Gunung Jembrana yang berjumlah 33 orang. Dalam 
penelitian tersebut dikategorikan sebagai penelitian populasi sebab semua populasi telah dijadikan sebagai unit pengamatan atau sasaran penelitian.

Dalam melakukan pengumpulan data akan digunakan sebuah teknik kuesioner. Penelitian ini menggunakan teknik kuesioner untuk mendapatkan data. Kuesioner itu sendiri dapat diartikan sebagai sebuah teknik untuk mendapatkan data dengan menyebarkan atau memberikan kertas yang di dalamnya terdapat pertanyaan ataupun pernyataan yang berhubungan dengan topik penelitian yang diberikan kepada pihak-pihak yang memiliki sangkutan dengan penelitian tersebut. Data penelitian ini dianalisis dengan memakai analisis jalur dimana tujuannya untuk dapat menganalisis suatu pola hubungan yang tidak langsung. Analisis ini juga dapat dimanfaatkan untuk tahu pengaruh totalan dan pengaruh variabel penelitian yang meliputi kompensasi dan kepuasan kerja pada kinerja dari karyawan pada CV. Prabu Tirta Gunung Jembrana. Olah data untuk analisis jalur dalam penelitian juga akan menggunakan program dari Statistical Package for Social Sience (SPSS) 21.0 for Windows.

Adapun penjelasan lebih rinci dari uji validitas dan reliabilitas adalah sebagai berikut. Kriteria pengujian dari uji reliabilitas dapat diuraikan sebagai berikut: (1) Item dikatakan valid apabila $p$-value < alpha $(\alpha)$ 0,05 maka item instrumen tersebut dinyatakan valid, (2) Item instrumen dinyatakan tidak valid apabila $p$-value > alpha ( $\alpha$ ) 0,05 maka item instrument tersebut dinyatakan tidak valid. Adapun kriteria pengujian dari Reliabilitas adalah Menurut Sugiyono (2009) Uji reliabilitas yang berkaitan dengan kadar konsistensi serta stabilitas data ataupun temuan. Dari penilaian positivstic (kuantitatif), data tersebut dapat disebut reliabel jika responden atau pihak yang menjawab secara konsisten. Kriteria dari suatu instrumen penelitian dikatakan reliabel adalah apabila koefisien reliabilitas (ri ) $>0,60$. Pengolahan data dalam penelitian ini dilakukan dengan bantuan program Statistical Package for Social Science (SPSS) 21.0 For Windows.

Paradigma atau diagram jalur penelitian terdiri dari empat buah sub struktur, yaitu (1) Pengaruh kompensasi $\left(\mathrm{X}_{1}\right)$ terhadap kinerja karyawan $(\mathrm{Y}),(2)$ Pengaruh kepuasan kerja $\left(\mathrm{X}_{2}\right)$ terhadap kinerja karyawan $(\mathrm{Y})$, (3) pengaruh kompensasi $\left(\mathrm{X}_{1}\right)$ terhadap kepuasan kerja $\left(\mathrm{X}_{2}\right)$, dan (4) pengaruh kompensasi $\left(\mathrm{X}_{1}\right)$ terhadap kinerja $(\mathrm{Y})$ melalui kepuasan kerja $\left(\mathrm{X}_{2}\right)$.

Tabel 1, Sumbangan Pengaruh Variabel (X1) terhadap (Y) Melalui (X2)

\begin{tabular}{lc}
\hline \multicolumn{1}{c}{ Keterangan } & Besar Sumbangan \\
\hline Besar pengaruh langsung $\mathrm{X}_{1}$ terhadap $\mathrm{Y}$ & $\mathrm{Pyx}_{1}$ \\
Besar pengaruh tidak langsung $\mathrm{X}_{1}$ melalui $\mathrm{X}_{2}$ & $\mathrm{Px}_{1} \mathrm{X}_{2}$ \\
terhadap $\mathrm{Y}$ & $\left(\mathrm{Pyx}_{1}\right)+\left(\mathrm{Pyx}_{1} \cdot \mathrm{Px}_{2} \mathrm{x}_{1} \cdot \mathrm{Pyx}_{2}\right)$ \\
Besar pengaruh total $\mathrm{X}_{1}$ terhadap $\mathrm{Y}$ & $\mathrm{Pyx}_{2}$ \\
Pengaruh langsung $\mathrm{X}_{2}$ terhadap $\mathrm{Y}$ & $\mathrm{R}^{2} \mathrm{yx}_{1} \mathrm{X}_{2}$ \\
Besar pengaruh total $\mathrm{X}_{1}$ dan $\mathrm{X}_{2}$ terhadap $\mathrm{Y}$ & $1-\mathrm{R}^{2} \mathrm{yx}_{1} \mathrm{X}_{2}$ \\
Pengaruh lain terhadap & \\
\hline
\end{tabular}

\section{Hasil dan Pembahasan}

Model analisis yang digunakan pada penelitian ini yaitu analisis jalur (Path Analysis). Pengujian ini dilakukan dengan bantuan SPSS 21.0. maka dapat diperoleh struktur pengaruh kompensasi terhadap kinerja melalui kepuasan kerja karyawan pada CV. Prabu Tirta Gunung Jembrana dapat dilihat pada Gambar 1 


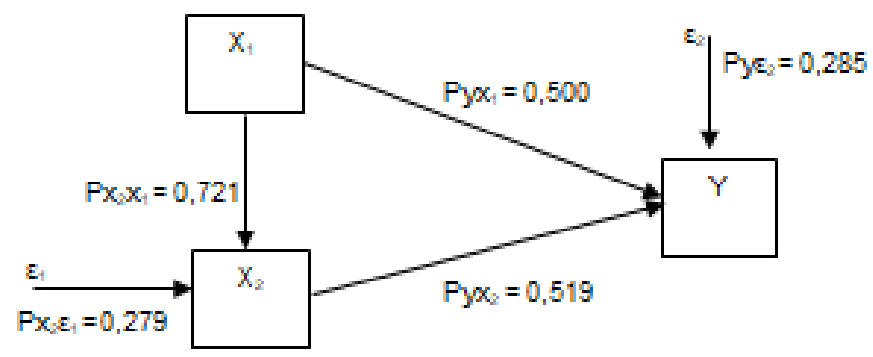

Gambar 1. Struktur pengaruh kompensasiterhadap kinerja melalui kepuasan kerja karyawan pada CV. Prabu Tirta Gunung Jembrana

Besar pengaruh langsung dan tidak langsung dari Kompensasi $\left(\mathrm{X}_{1}\right)$ terhadap Kinerja $(\mathrm{Y})$ melalui Kepuasan Kerja $\left(\mathrm{X}_{2}\right)$ dalam penelitian ini dapat dilihat pada Tabel 2

Sumbangan Pengaruh Variabel Kompensasi terhadap Kinerja melalui Kepuasan Kerja Karyawan.

Tabel 2, Sumbangan Pengaruh Variabel Kompensasi terhadap Kinerja melalui Kepuasan Kerja Karyawan

\begin{tabular}{lcc}
\hline \multicolumn{1}{c}{ Keterangan } & $\begin{array}{c}\text { Besar } \\
\text { Sumbangan }\end{array}$ & Persentase \\
\hline $\begin{array}{l}\text { Besar pengaruh langsung } X_{1} \\
\text { terhadap } Y\end{array}$ & 0,500 & $50,0 \%$ \\
Besar pengaruh tidak langsung $X_{1}$ & 0,374 & $37,4 \%$ \\
melalui $X_{2}$ terhadap $Y$ & 0,687 & $68,7 \%$ \\
Besar pengaruh total $X_{1}$ terhadap $Y$ & 0,519 & $51,9 \%$ \\
Pengaruh langsung $X_{2}$ terhadap $Y$ & 0,715 & $71,5 \%$ \\
Besar pengaruh total $X_{1}$ dan $X_{2}$ & 0,285 & $28,5 \%$ \\
terhadap $Y$ & & \\
Pengaruh lain terhadap $Y$ & &
\end{tabular}

Kinerja karyawan diberi pengaruh atas variabel kompensasi di CV. Prabu Tirta Gunung Jembrana. Hasil tersebut sebesar 0,500 yang mana $p$-value yang dihasilkan itu besarnya 0,004. Berarti kalau kompensasi itu didapatin pengaruh secara positif pada kinerja dari karyawannya yang memiliki besaran $68,7 \%$.

Kinerja karyawan diberi pengaruh atas variabel kepuasan kerja di CV. Prabu Tirta Gunung Jembrana. Hasil tersebut sebesar 0,519 yang mana p-value yang dihasilkan itu besarnya 0,002. Berarti kalau kepuasan kerja itu didapatin pengaruh secara positif pada kinerja dari karyawannya yang memiliki besaran $51,9 \%$.

Kepuasan kerja dari karyawan diberi pengaruh atas variabel kompensasi di CV. Prabu Tirta Gunung Jembrana. Hasil tersebut sebesar 0,721 yang mana $p$-value yang dihasilkan itu besarnya 0,000. Berarti kalau kompensasi itu didapatin pengaruh secara positif pada kepuasan kerja karyawan.

Kinerja itu diberikan pengaruh kompensasi dengan melalui variabel lain yaitu kepuasan kerja. Kompensasi sama kepuasan kerja ini bareng-bareng beri pengaruh pada kinerja karyawan. Hasilnya adalah p-value nya itu 0,000 . Jadi secara bareng-bareng itu kedua variabel itu beri pengaruh pada kinerja karyawan dengan besaran $71,5 \%$ dan variabel lain itu beri pengaruh $28,5 \%$.

Penelitian yang dibuat ini mendapatkan hasil kalau sub variabel kompensasi itu beri efek pada kinerja karyaan yang mana kompensasi memberikan efek positif terhadap kinerja karyawan pada CV. Prabu Tirta Gunung Jembrana. Pada hasil penelitian tersebut searah dengan pendapat dari Mathis dan Jakson (2006) yaitu upaya yang dilakukan manajemen dalam proses peningkatan kinerja karyawannya itu adalah memberikan bonus berupa 
kompensasi. Kompensasi ini juga dapat memberikan dorongan untuk dapat meningkatkan kinerja pekerjanya (Hasibuan, 2009).

Dari hasil penelitian berikutnya dapat diperoleh dari variabel kepuasan kerja yang memberikan efek yang positif untuk kinerja karyawan pada CV. Prabu Tirta Gunung Jembrana adalah 0,519 atau sebesar $51,9 \%$ dan besar sumbangan efek kepuasan kerja untuk kinerja karyawan adalah sebesar $26,9 \%$. Hasil penelitian ini sama dengan pendapat dari Robbins (2012) yaitu seseorang yang punya rasa puas yang bagus dan tingi ini akan punya rasa positive dalam pekerjaannya, sedangkan beberapa orang yang tidak memiliki tingkat kepuasan dalam pekerjaannya, sehingga karyawan yang punya rasa puas ini nanti dapat dinyatakan punya kinerja yang baik juga nanti. Selain itu adapun menurut teori dari Affandi (2016) menyatakan bahwa kepuasan kerja juga juga dapat meningkatkan kinerja, sehingga pekerja akan merasa puas serta bisa lebih kreatif dalam bekerja.

Dalam penelitian selanjutnya membahas tentang pengaruh kompensasi untuk kepuasan kerja yang menyatakan bahwa kompensasi yang memberikan efek yang positif untuk kepuasan kerja pada CV. Prabu Tirta Gunung Jembrana adalah 0,721 atau sebesar $72,1 \%$, besar sumbangan efek kompensasi untuk kepuasan kerja sebesar $27,9 \%$. Hasilnya sama dengan pendapat dari Sunyoto (2012) katanya bahwa sistem kompensasi yang baik ialah sistem kompensasi nantinya yang didapat sama karyawan bisa buat rasa puasnya meningkat juga. Pendapat tersebut didukung juga oleh penelitian dari Putra (2016) yang menyatakan bahwa adanya pengaruh dari kompensasi terhadap kepuasan kerja. Rendahnya kompensasi yang dikasih ke karyawan nantinya menyebabkan karyawan kurang puas akan hasil dari pekerjaannya.

Hasil penelitian dari variabel kompensasi terhadap kinerja melalui kepuasan kerja karyawan yang memberikan efek yang positif sejumlah 0,715 Hasil tersebut menunjukkan bahwa sejumlah $71,5 \%$. kinerja karyawan dipengaruhi oleh variabel kompensasi dan kepuasan kerja, besar sumbangan pengaruh dari kompensasi terhadap kinerja melalui kepuasan kerja sejumlah 0,285 atau sejumlah $28,5 \%$. Hasil ini sesuai dengan penelitian yang dikemukakan oleh menurut Putra (2016) yang menyatakan bahwa adanya pengaruh positive dari kompensasi dan kepuasan kerja terhadap kinerja karyawan. Semakin sesuai gaji atau kompensasi yang didapatkan oleh pihak karyawan maka karyawan akan merasa puas dan mampu meningkatkan kinerja.

Hasil penelitian ini menyatakan bahwa kompensasi secara langsung lebih berpengaruh terhadap kinerja karyawan dengan jumlah sebesar 0,500 dari pada harus melalui kepuasan kerja dengan jumlah sebesar 0,374. Oleh sebab itu, diharapkan perusahaan lebih memperhatikan dalam pemberian kompensasi, sebab pemberian kompensasi yang sesuai dapat meningkatkan kinerja karyawan. Hal ini sejalan dengan pendapat dari Hasibuan (2009) pemberian sebuah kompensasi yang memadai dapat mendorong peningkatan dari kinerja karyawan tersebut.

Adapun keterbatasan dari penelitian ini yaitu peneliti cuma memakai satu perusahaan saja, oleh karena itu, jadinya hasilnya itu tidak bisa diaplikasin pada lain. Selain itu, pada bagian populasi juga yang digunakan dalam penelitin ini masih sedikit. Maka, untuk peneliti yang lainnya harusnya buat penelitian dengan memakai perusahaan yang lebih banyak dan besar biar hasil yang didapatkan juga maksimal.

\section{Simpulan dan Saran}

Atas dasar hasil serta pembahasan maka terdapat kesimpulan sebagai berikut. Mendapatkan hasil jika kompensasi ini memberikan efek pada kinerja dari karyawan pada CV. Prabu Tirta Gunung Jembrana dengan jumlah sebesar 0,500 dari pada harus melalui kepuasan kerja dengan jumlah sebesar 0,374. Oleh sebab itu, diharapkan perusahaan lebih memperhatikan dalam pemberian kompensasi, sebab karyawan yang mendapatkan kompensasi akan memberikan kinerja yang dapat ditingkatkan pula. Saran yang akan diberikan adalah (1) Bagi pihak perusahaan CV. Prabu Tirta Gunung Jembrana, untuk dapat meningkatkan kinerja dari para karyawan, diharapkan kepada pihak perusahaan untuk lebih memperhatikan dalam pemberian kompensasi dengan memperhatikan kepuasan kerja dari 
karyawan dengan melalui pemberian gaji yang sesuai dengan UMK, maka karyawan akan berusaha untuk meningkatkan kinerja sehingga akan terciptanya kinerja karyawan yang maksimal, (2) Untuk peneliti yang ingin melakukan penelitian yang sama yaitu dengan menggunakan variabel kompensasi, kepuasan kerja, dan kinerja karyawan kami harap untuk bisa dikembangkan lagi penelitian ini agar hasil penelitian ini dapat digunakan secara umum serta diharapkan dapat mencari atau menambahkan faktor-faktor lain yang mungkin dapat mempengaruhi peningkatan kinerja karyawan terhadap perusahaan.

\section{Daftar Pustaka}

Affandi, P. 2016. Cocept \& Indicator, Human Resouce Management for Management Reseacr. Edisi 1, Cetakan 1. Yogayakarta: Deepblish

Berdasarkan Kemenprindag. No. 704/MMP/Kep/11/2003 Persyaratan Teknis Industri Air. (Diakses Pada Tanggal 19, November 2019)

Darmaja, E. Y. 2015. Pengaruh Kepemimpinan Dan Kepuasan Kerja Terhadap Kinerja Karyawan Di perusahaan Daerah Tingkat 1 Bali Sub Unit Sangiang Tahun 2013. Jurnal Pendidikan Ekonomi Undiksha. Vol 5 No. 1.

Hasibuan, M. S. P. 2009. Manajemen Dasar Penelitian Dan Masalah. Jakarta: PT. Bumi Akasara

Hasibuan, Melayu. S. P. 2012. Manajemen Sumber Daya Manusia. Jakarta: PT. Bumi Aksara

Hendro, T. 2018. Pengaruh Kompensasi Dan Kepuasan Kerja Terhadap Kinerja Karyawan Tetap CV. Karya Gemilang, AGORA. Vol 6. No. 1.

Irianto, Agus. 2004. Statistik: Konsep Dasar Aplikasi dan Pengembangan. Jakarta: Prenada Media Group.

Kuswadin. 2004. Cara Mengukur Kepuasan Karyawan. Jakarta: PT. Elex Media Komputindo.

Luthans, Fred. 2006. Perilaku Organisasi. Yogyakarta: ANDI

Mangkunegara, Anwar Prabu. 2005. Perilaku dan Budaya Organisasi. Cetakan Pertama. Penerbit Refika Aditama, Bandung.

Mangkunegara. A. P. 2009. Manajemen Sumber Daya Manusia. Bandung: Perusahaan Rosta.

Mathis. R. L, Jackson. J. H., \& Valentina. S. R. 2016. Human Resource Management: Essential Perspectives ( $7^{\text {th }}$. ed). Boston: Cengage Learning.

Nawa, F., \& Kempa, S. 2017. Pengaruh Kompenssi Dan Disiplin Kerja Terhadap Kinerja Karyawan Pada PT. PLN Wilayah Nusa Tengara Timur. AGORA. Vol 5. No. 3

Novita. 2016. Pengaruh Kepuasan Kerja Dan Komitmen Organisasional Terhadap Kinerja Karyawan Studi Pada PT. Telekomunikasi Indonesia, Jatim Selatan Malang. Jurnal Administrasi Bisnis. Vol. 34. No. 1.

Putra, I. B. A. K., Bagia, I. W., \& Suwendra, I. W. 2016. Pengaruh Kompensasi Dan Kepuasan Kerja Terhadap Kinerja Karyawan. e-Journal Bisma Universitas Pendidikan Ganesha. Vol 4. No. 1-9. 
Robbins, Stephen. 2012. Perilaku Organisasi. Jakarta: Salemba Empat.

Simamora, Henry. 2004. Manajemen Sumber Daya Manusia. Edisi ketiga. Yogyakarta: STIE YKPN.

Sudaryo, Y., \& Dkk. 2018. Manajemen Sumber Daya Manusia Kompensasi Tidak Langsung Dan Lingkungan Kerja. Yogyakarta: CV. Andi Offset.

Sugiyono. 2009. Model Penelitian Kuantitatif Kualitatif Dan R\&D. Bandung: Alfabeta.

Sunyoto, Danang. 2012. Teori, Kuesioner, dan Analisis Data Sumber Daya Manusia (Praktik Penelitian). Yogyakarta: CAPS

Wirawan. 2009. Evaluasi Kinerja Manajemen Sumber Daya Manusia. Jakarta: Salemba Empat. 